\title{
Basic Psychological Needs in Childhood and Adolescence
}

\author{
Michael Borg-Laufs* \\ Niederrhein University of Applied Sciences, Mönchengladbach, Germany
}

\begin{abstract}
In this article, four basic psychological needs, derived from psychological basic research, are presented. These are the needs for orientation and control, pleasure gain/distress avoidance, self esteem protection, and attachment. It is argued, that the satisfaction or violation of these needs has a main impact on the development of children and adolescents. To take these needs into account in various areas of pedagogical and psychosocial work gives good opportunities to help children and adolescents developing in a desired direction. The use of this concept is helpful in western societies as well as in developing countries.
\end{abstract}

Keywords: basic psychological needs, child development, adolescence, attachment

\section{Basic Psychological Needs}

There is a long tradition of thinking about basic psychological needs in psychology, starting with Freud (1905) and Adler (1917). The most well-known concept of basic needs may be that of Maslow (1954). It was a hierarchic model: only in case the physical needs of someone are satisfied, he or she begins to care about psychological needs and only in case these are satisfied humans start caring about spiritual needs. These older concepts of basic needs were not really empirically grounded. The American psychologist Epstein (1990) then developed a concept of basic psychological needs, which was founded on the empirical findings of psychological research. Grawe (2006) elaborated this concept in a much extended way and published path-breaking works about the importance of this concept for understanding human behavior and even more to help patients with severe psychological problems. In their publications, Grawe and his team always strengthened the point that their work is all about adult persons (patients). Regarding this, we started some research and work on transmitting this concept for the psychosocial work with children and adolescents (Borg-Laufs \& Dittrich, 2010; Borg-Laufs, 2012).

In this model, there are four psychological needs highlighted. These are the needs for

- orientationen/control,

- self esteem protection,

- pleasure gain/distress avoidance,

- attachment. 
In the following sections, these four needs and their meaning for everyday life will be explained.

\section{Orientation and Control}

We all want to have the impression, that we can understand and influence the world around us. Nobody wants to see himself or herself as a victim of circumstances he or she can't understand and manipulate. Such an impression would lead to helplessness, passivity and a poor attitude towards life. Some major psychological findings and theories describe the special role of the need of orientation and control for a good life, so does the concept of self-efficacy (Bandura, 1997) and the theory of the sense of coherence, described by Antonovsky (1987). Children need consistent acting caregivers for living in a comprehensible world, who give enough structure on the one hand and on the other hand let their children take part in decisions regarding their development, not overwhelming and not overprotective. Experiences of loss of control in childhood have a deep impact on further development: studies show very obviously, that violations of the need for control are very harmful for mental health (Grawe, 2006). Especially, the vulnerability for adaption disorders, postraumatic stress disorders, anxiety disorders and compulsive disorders may rise, if the need for orientation and control is vulnerable.

Adolescents are still searching for orientation, therefore, they identify compassionately with movie stars, musicians or famous sportsmen and -women. Even more, they are influenced by their peer group (Berndt, 1992). But on the other hand, adolescents are trying to reach full autonomy, which means, that getting control over their life is one of their main developmental goals (Havighurst, 1948; Mattejat, 2008). The main conflicts between adolescents and their parents or teachers are all about control. Obviously, it is a very difficult task for parents to give up control and responsibility for their children when they are growing up into adulthood.

\section{Self Esteem Protection}

It is immediately apparent that a negative self-assessment leads to mental suffering. People want to assess themselves as "good" or at least "okay". In fact, we all tend to estimate ourselves a little better as it would withstand an objective view (Grawe, 2006). As long as this subjective assessment, however, is not too different from what other people think, this is not a problem, but rather a protective factor. Mentally healthy people are concerned mainly with the experiences in which they have performed above average. If there can't be any doubt that we did something badly, we tend to attribute situational causes, so the problem is less to see in ourselves and more in the adverse conditions. A serious negative view of ourselves, however, can lead to many problems, such as to depressive disorders or social anxiety.

Children need to experience success and appreciative feedback from their significant others to satisfy their need for self-protection. Constant criticism, devaluation and abuse by parents undermine the satisfaction of this basic need. A particularly dramatic violation of the need for self-protection is experienced by abused and/or battered children. Since they are dependent on their caregivers in an existential manner, they cannot bear to judge their caregivers (mostly their parents) bad. If they are battered 
by their own parents, they are faced with the choice, either to review their parents as "bad" (because they beat them for no reason) or themselves (because they were behaving badly and have been beaten for that reason). Especially, young children blame themselves in this situation for the abuse they experience. Choosing this alternative, they can go on assessing their parents as "good" (Borg-Laufs \& Dittrich, 2010, p. 11).

In the further course of development humans still are trying to avoid experiences that decrease their self esteem. For example, school avoidance of adolescents can be understood in this context. Thimm (2000, p. 118) describes school-absenteeism as a "result of a process of increasing alienation and disintegration" in school. Also aggressive youths mostly have problems with a low self-esteem (Wagner, 2010). Highly aggressive adolescents often have a biography of decreasing self-esteem experiences with parents, peers, and in school (Borg-Laufs, 2002). Their aggressive behavior can be understood as an attempt to increase their self-esteem by dominating other people.

\section{Pleasure Gain and Distress Avoidance}

It is easy to understand the power of this basic need in everyday life. People evaluate their experiences and the situations in which they find themselves, and the stimuli (in the sense of learning theory) which are presented to them, on a dimension with the values "good" and "bad", and this evaluation usually leads to approaching behavior (when something is experienced as "pleasant") or avoiding behavior (for unpleasant stimuli).

Many psychological theories consider that people try to avoid distress and to gain pleasure. While in psychoanalysis, the libido is considered the central source of motivation, in learning theory, operant conditioning can only be understood if one considers it to be true, that people want to gain pleasure and to avoid distress. Other theories (such as "flow", Csikszentmihalyi, 2008) draw on this need too. Developmental research shows that operant conditioning already works in early childhood (Siqueland, 1968).

It should be noted that the perception of pleasure or displeasure is not determined by objective qualities, but that it is rather the result of emotional and cognitive appraisal processes. Although there are strong biological and cultural determinations, there is a great inter-individual diversity in what people like and dislike. This is one reason why reward programs tend to fail if they are not personalized (BorgLaufs \& Hungerige, 2007).

The younger humans are, the more is the need for pleasure gain and distress avoidance determining their actual behavior because they have to learn needs deferment during their childhood and youth. Growing older they will learn more and more to wait for gratifications so that they can stand some distress if they know there will be pleasure later on. It appears that this seems to be a key ability for leading a successful life (Mischel et al., 2011). 


\section{Attachment}

Attachment means deep emotional relationships to important, usually not easily changeable, caregivers. After initial investigations that showed the importance of attachment in a dramatic way (Spitz, 1971) and grounded on the work of Bowlby (1983), it has been Ainsworth, Blehar, Waters, and Wall (1978), who did research on attachment. Subsequently, there was a lot of developmental research on this subject (Grossmann \& Grossmann, 2008; Brisch \& Hellbrügge, 2006).

According to Ainsworth et al. (1978), attachment behavior of children is divided into four different categories. Children with a secure attachment style are trying to get near to their bonded persons (usually parents or foster parents), to be comforted by them. The parents of secure attached children usually show sensitive behavior, they perceive the child's needs and respond quickly and appropriately (sensitive, accepting, collaborating) to them (Maccoby, 1980). The children calm down quickly and start again to explore their environment. A secure attachment style develops through the experience of emotional availability of caregivers in stressful situations.

Children with insecure-avoidant attachment style do not try to get help from their caregivers in emergency situations. They have made the experience, that they are not supported in emotional distress, but will be devalued and rejected when they ask for help. Therefore, they avoid further rejection by presenting themselves in a "cool" manner (even if they are highly distressed) and do not demand for support. Insecureambivalent attached kids show high emotional involvement by weeping and clinging to the person they want to be near to. They do this because they have learned, that they only have a chance to get comfort and care when they show their needs in a dramatic way.

Some children behave in unexpected ways. They often behave in an aggressive way, sometimes bizarre. This behavior is a sign of a disoriented attachment style; it seems like they have not developed any attachment to specific people. This behavior is to be viewed as a result of traumatic experiences of abuse, neglect or frequent changing caregivers. These children suffer from an attachment disorder (Gahleitner, 2008).

The psychological mechanisms underlying the different attachment styles have an impact on the relationship behavior in adolescence and adulthood (Grossmann \& Grossmann, 2008). Secure attached children show good social skills, have a lot of friends, show a realistic and positive view of life and are dealing flexibly with problems. In contrast, insecure-avoidant attached children and adolescents distrust others, idealize their own skills and are aggressive. Insecure-ambivalent attached children try to gain support and comfort by showing shy and affectionate behavior when they grow older.

Attachment disorders in childhood are precursors of massive disturbances in adolescence and adulthood. The affected children suffer from a profound emotional and social immaturity and are in need of emotionally resilient, loving and at the same time consistent caregivers (foster or adoptive parents, educators) (Rygaard, 2006). In fact, we don't know very much about the therapeutic treatment of these children (von Klitzing, 2009). However, there is some evidence, that the distinction between inhibited and disinhibited attachment disorders is prognostically relevant: even under new good conditions (having good foster care), the disinhibited children (who tend to make friends 
with everyone, but cannot go into deep, meaningful relationships) are often developing not very well (Zeneah, Smyke, Koga, \& Carlson, 2005).

There is clear evidence, that a secure attachment between parents and their children has an enormous impact on adolescence, too. It appears that secure attached adolescents are much less likely to develop emotional or social problems then their insecure attached colleagues (Kerns \& Stevens, 1996; Cooper, Shaver, \& Collins, 1998). For this reason, it has to be a main issue of parenthood even with adolescents to support secure attachment. Regarding all the developmental tasks of their adolescent children (e.g. gaining control over their life, see above), this means to be psychologically available, to establish and continue a warm and loving atmosphere, and negotiate limits and rules instead of determining them (Allen, Moore, Kuperminc, \& Bell, 1998).

\section{The Meaning of Basic Psychological Needs in Pedagogical and Psychosocial Work}

Psychosocial support as well as pedagogical work for children should take the satisfaction of basic psychological needs into account, if we assume that a happy life is closely linked to the satisfaction of these basic needs. People working with children and adolescents can adopt the basic need perspective, to see if they can provide assistance to support the children in the experience of basic need satisfaction.

Attachment orientation in psychosocial and pedagogical work means to give the child a reliable relationship offer. In counseling of parents, there should be a focus on giving them advice on how to achieve an improvement in the parent-child-relationship. This can be done not only by strengthening family rituals, but also by increasing free time for the parent and the child together. The older the children are, the more important are also non-family relationships, and in many contexts good and helpful relationship experiences outside the family can mitigate family stress.

If we focus on the learning process in school and at home, we can recognize that this process is also mainly influenced by the quality of the relationship to teachers and parents. It is an essential characteristic of successful attachment that children in distress ask the persons they can trust in for help. If they experience punishment or disrespectful answers when they ask for help (like "You once again were not paying attention! That is horrible!" or similar answers), they will not ask again in future and the probability that a child gets appropriate help decreases. Instead of that, children need teachers and parents who try to have a close contact and relationship with them, so that they can be sure to get help in a respectful way, when they ask for it.

Pedagogical work which focuses on self esteem protection of the children emphasizes and strengthens the skills of the children. Concentrating the pedagogical activities on the resources of the children means not to discuss their difficulties, but always to focus on what has been achieved and to chose challenges which the children can cope with. If the children or adolescents show self-narratives which are devaluating, teachers and parents should question them and try to change them.

The consequence for learning contexts is simple: encouragement, constructive feedback and praise for learning-related activities are helping pupils to strengthen their self-esteem while working for school. Devaluation and blame on the other hand 
lead to less school-related activities in future. Some children or adolescents probably will keep their negative self-concept for a long time, being "immune" to praise and encouragement. There are children and adolescents with a lot of failure school experiences. Positive feedback does not fit to their self-concept, while negative feedback is consistent with their view of themselves and therefore better integrated (Petersen, Stahlberg, \& Dauenheimer, 2000). In these cases, teachers need a great deal of patience and even more focusing on the resources of the children and adolescents.

Orientation and control can be incorporated in various ways in psychosocial support and pedagogical work. Confidence in one's own capabilities leads to effective actions. Adolescents with high self-efficacy are able to go on with learning behavior even if there are other attractive offers for spending their time (Schwarzer \& Jerusalem, 2002). It is necessary to support children in the development of high self-efficacy, if we want them to be good learners. Therefore, their education should be encouraging. Adults should give them help if they want and need it, so that they can achieve their goals even better. This assistance should be based on the concept of the "zone of proximal development" by Vygotski (1978). This means to give the children challenges, which are a little bit harder as what they could do until now without help and to assist them on a low level by overcoming these challenges. Therefore, it is necessary to detect the current achievement-level of the child and accurately provide the help which is needed to achieve the next higher level. This can be enhanced through instruction (in the classroom, while practicing at home) but also in a playful situation or by creating a stimulating environment.

If helpers are working in a one-to-one-situation with the child or adolescent, they should make sure whether the child wants to have more guidance (orientation) or more autonomy (control). If the child needs orientation and guidance, the helper should make the decisions what should be done next. If the child wants to have more control, it is important to let the child or adolescent participate on such decisions or leave them all to him or her.

At least, teachers and social workers should remember that children need solid structures and that rituals in pedagogic contexts can be beloved landmarks for the children.

To make experiences of pleasure happen, beneficial activities should be chosen. To follow the interests of the child and play with him according to his wishes can give the child the impression of successful everyday experiences. At another level of interaction, it is necessary for efficacious psychosocial work with youths to share interests and maybe joyful activities with them. As we know from the work of Csikszentmihalyi (2008), it is quite possible, even in challenging (but not too challenging) performance situations to feel great happiness. This full absorption in an activity, which is called "flow", is a result of self-chosen, yet challenging activities.

Meanwhile there are some (German) publications in which the specific needs of selected groups of clients are taken into consideration. Armbruster (2006) developed an empirically revisited concept of preventive work with multi-problem families; heavily relying explicitly on the basic psychological needs (see also the basic need-based approach for working with poor families from Borg-Laufs, 2010a). For therapeutic and 
educational work with children of mentally ill parents there are also ideas for analyzing the basic needs of the children and adolescents (Borg-Laufs, 2010b). Immisch (2011) presents an attachment-oriented cognitive-behavioral approach for working with change-resistant adolescents. The assessment of child welfare risks can and should take into consideration; whether basic needs of the children are hurt (Dittrich \& Borg-Laufs, 2010, 2011).

The concept of psychological basic needs is now being applied to other contexts of working with children, youth and families, such as on educational processes in general (Klemenz, 2009), school (Borg-Laufs, Fengler, \& Krus, 2010), social work in school (Rohleder, 2010) youth work (Krajewski, Dittrich, \& Borg-Laufs, 2010) and for psychomotoric therapy (Krus, 2004).

\section{A Brief Case Study of Analyzing the Satisfaction of Psychological Needs}

Manuela, a German girl of 8 years of age, lived with her manic-depressive single-parent mother. Two years ago, her father (who didn't suffer from a psychiatric disorder) left the family and because of the major disputes between the parents the contact between the father and the rest of the family was cut off. Since the father left the family, the daily life of the family changed dramatically. Her mother was trapped in her own problems and was not able to take care of the needs of her daughter. In the manic phases, the mother acted completely unpredictable. Manuela never knew, for instance, whether her mother would be at home when she comes home from school or not. In case she was at home, the days had no predictable structure. Sometimes, there was something to eat, sometimes, nothing. Manuela had no clue at all, what would happen next. In the depressive phases, Manuela had to take care for herself and for her mother. She did the laundry, cooked the food and cleaned the flat. Her mother had no time for her, whether she was manic or depressive. In the manic phases she followed her personal wishes and impulses and usually went out to meet other people. In the depressive phases, she spent her time mainly in bed, barely speaking or interacting. She did not take the pills she was told to take. The teachers in school realized that Manuela was very tired every day and sometimes fall asleep during the lessons. Additionally, she often went to school in inappropriate clothes (especially in winter), had usually no school snack with her and seemed to be in a sad mood most of the time. So, they called the child welfare services and the social workers took her away from her mother and placed her in an orphanage home. The first months when she was living there, she was very unhappy because she felt responsible for the welfare of her mother. Furthermore, she wanted to take care for all the other children around her. Though she needed time, she started getting better as she established a good and strong relationship to one of the women working in the orphanage and as she got psychotherapeutic help.

Speaking in terms of basic psychological needs, she had a low self esteem, because she learned that nobody cared for her (her father left her and her mother was not able to take care) and so she thought she is not worth being cared for. She had no orientation in her life because she never knew what was happening at home and there were no rules and rituals. So, she began to take control and responsibility in a way which is inappropriate for a young child and she couldn't stop this when she had a new 
place to live, although nobody expected this behavior from her there and she had a lot of conflicts with the other children and the teachers because of her controlling behavior. She was in need for someone she could feel attached to, because for the last 2 years, she had nobody being lovingly towards her. She needed the structured life in the orphanage home, although she first fought against losing control, she needed to feel welcomed and loved and she needed some professional help to work on her self-esteem.

\section{Using the Concept of Psychological Needs in Developing Countries}

In many areas of education and of psychosocial work with children, the concept of basic psychological needs helps to understand the children's problems more properly and to develop helpful interventions although there is of course a need for further research on that topic.

This concept was developed in the western industrialized world. Nowadays, in these countries, there is acceptance for the included ideas like children need love and attachment or children are hurt in self-esteem and their need for control when they get corporal punishment. Fifty years ago, some of the ideas would have been far away from the usual practice in America or Europe, which is obvious if you take into account how children in orphanage homes were treated in that time (Spitz, 1971) or that it was very normal to beat children when they behaved inappropriately at home as well as in school. It is less than fifty years ago that there came a new law in Germany which prohibited beating of pupils by their teachers and it is little more than ten years ago since there is a law against parental violence. In Nepal, it is pretty normal to beat children who misbehave at home and it is forbidden in school only a few years back. So, you might get the idea that the time for the concept of psychological needs of children and adolescents is still not risen in developing countries, because there are more basic problems in working with families like parents' attitudes towards schooling (Bharati $\&$ Takao, 2010). Besides these very basic problems, of course, there is a need for solving more differentiated educational (Basnet \& Banskota, 2010; Rybak, Marjahan, \& Adhikari, 2010) and clinical (Shakya, 2010) problems.

The concept of basic psychological needs is easy to integrate in professional training and provides a lot of ideas to understand educational as well as psychiatric problems in a better way. Of course, it is necessary to adapt the concept in a cultural sensitive way for example in training programs for teachers or counsellors (Tol, Jordans, Regmi,\& Sharma, 2005). Counselling as an important service for adults and children has only yet started in Nepal but needs to expand (Tol, Jordans, Keen, \& Pradhan, 2007). As far as the author of this article knows, there is only one Child Guidance Clinic in Nepal right now. Child Guidance Clinics are places where help for children, adolescents and parents is provided. If this service would be expanded, the concept of basic psychological needs of children and adolescents could be used in the training of the professional helpers working there as an easy to use concept of understanding family problems. 


\section{References}

Adler, A. (1917). Study of organ inferiority and its psychical compensation. New York: The Nervous and Mental Disease Publishing Company.

Ainsworth, M. D. S., Blehar, M., Waters, E., \& Wall, S. (1978). Patterns of attachment: A psychological study of the strange situation. Hillsdale: Erlbaum.

Allen, J. P., Moore, C., Kuperminc, G., \& Bell, K. (1998). Attachment and adolescent psychosocial functioning. Child Development, 69, 1406-1419.

Antonovsky, A. (1987). Unraveling the mystery of health - How people manage stress and stay well. San Francisco, CA: Jossey-Bass Publishers.

Armbruster, M. (2006). Eltern-AG. Das Empowerment-Programm für mehr Elternkompetenz in Problemfamilien. Heidelberg: Carl-Auer.

Bandura, A. (1997). Self-efficacy: The exercise of control. New York: Freeman.

Basnet, S., \& Banskota, M. (2010). Inclusive education for transhumance groups in Himalayas: Educational policy challenge in Nepal. Journal of Education and Research, 2, 26-29.

Berndt, J. (1992). Friendship and friends' influence in adolescence. Current Directions in Psychological Sciences, 1, 156-159.

Bharati, S., \& Takao, H. (2010). Schooling: Knowledge, perception and practices of parents. Journal of Education and Research, 2, 44-51.

Borg-Laufs, M. (2002). Verhaltenstherapie mit aggressiven Jugendlichen - Ableitungen aus der Entwicklungspsychopathologie. In bkj (Ed.), Viele Seelen wohnen doch in meiner Brust - Identitätsarbeit in der Psychotherapie mit Jugendlichen (pp. 107131). Münster: Verlag für Psychotherapie.

Borg-Laufs, M. (2010a). Psychische Gesundheit von Kindern und Jugendlichen aus armen und armutsgefährdeten Familien. In V. Hammer \& R. Lutz (Eds.), Neue Wege aus der Kinderarmut (pp. 232-244). Weinheim: Juventa.

Borg-Laufs, M. (2010b). Die vergessenen Kinder: Über die Auswirkungen psychischer Krankheit von Eltern auf Kinder. In S. B. Gahleitner \& G. Hahn (Eds.), Klinische Sozialarbeit.Gefährdete Kindheit und Jugend - Risiko, Resilienz und Hilfen (pp. 122-130). Bonn: Psychiatrie-Verlag.

Borg-Laufs, M. (2011). Störungsübergreifendes Diagnostik-System für die Kinder- und Jugendlichenpsychotherapie (SDS-KJ). Tübingen: DGVT-Verlag.

Borg-Laufs, M. (2012). Die Befriedigung psychischer Grundbedürfnisse als Weg und Ziel der Kinder- und Jugendlichenpsychotherapie. Forum für Kinder- und Jugendpsychiatrie, Psychosomatik und Psychotherapie, 22, 6-21.

Borg-Laufs, M., \& Dittrich, K. (2010). Die Befriedigung psychischer Grundbedürfnisse als Ziel psychosozialer Arbeit. In M. Borg-Laufs \& K. Dittrich (Eds.), Psychische Grundbedürfnisse in Kindheit und Jugend. Perspektiven für Soziale Arbeit und Psychotherapie (pp. 7-22). Tübingen: DGVT-Verlag.

Borg-Laufs, M., Fengler, J., \& Krus, A. (2010). Wie lässt sich Lernentwicklung unterstützen? Lernen und ressourcenorientierter Unterricht aus der Perspektive der Entwicklungspsychologie. Pädagogik 6, 40-45.

Borg-Laufs, M., \& Hungerige, H. (2007). Operante Methoden. In M. Borg-Laufs (Ed.), Lehrbuch der Verhaltenstherapie mit Kindern und Jugendlichen, Bd. 2: 
Diagnostik und Intervention (pp. 415-454). Tübingen: DGVT.

Bowlby, J. (1983). Attachment. New York: Basic Books.

Brisch, K. H., \& Hellbrügge, T. H. (2006). Kinder ohne Bindung. Deprivation, Adoption und Psychotherapie. Stuttgart: Klett-Cotta.

Cooper, M. L., Shaver, P. R., \& Collins, N. L. (1998). Attachment styles, emotion regulation, and adjustment in adolescence. Journal of Personality and Social Psychology, 74, 1380-1397.

Csikszentmihalyi, M. (2008). Flow: The psychology of optimal experience. New York: Harper.

Dittrich, K., \& Borg-Laufs, M. (2010). Kindeswohlgefährdung und psychische Grundbedürfnisse. In M. Borg-Laufs \& K. Dittrich (Eds.), Psychische Grundbedürfnisse in Kindheit und Jugend. Perspektiven für Soziale Arbeit und Psychotherapie (pp. 87-98). Tübingen: DGVT.

Dittrich, K., \& Borg-Laufs, M. (2011). Qualifizierte Diagnostik im Bereich der Kindeswohlgefährdung: Der "Mönchengladbacher Befundbogen zur Kindeswohlgefährdung". In S. B. Gahleitner, K. Fröhlich-Gildhoff, F. Wetzorke, \& M. Schwarz (Eds.), "Ich sehe was, was du nicht siehst ..." Gemeinsamkeiten und Unterschiede verschiedener Perspektiven in der Kinderund Jugendlichenpsychotherapie (pp. 150-167). Stuttgart: Kohlhammer.

Epstein, S. (1990). Cognitive-experiential self-theory. In L.A. Pervin (Ed.), Handbook of personality: Theory and research (pp. 165-192). New York: Guilford.

Freud, S. (1905). Three essays on the theory of sexuality. New York: Basic Books.

Gahleitner, S. (2008). Kinder- und Jugendlichentherapie unter bindungstheoretischen Gesichtspunkten. Kindesmisshandlung und Vernachlässigung, 11, 51-66.

Grawe, K. (2006). Neuropsychotherapy. London: Erlbaum.

Grossmann, K., \& Grossmann, K.E. (2008). Elternbindung und Entwicklung des Kindes in Beziehungen. In B. Herpertz-Dahlmann, F. Resch, M. Schulte-Markwort, \& A. Warnke (Eds.), Entwicklungspsychiatrie (pp. 221-241). Stuttgart: Schattauer.

Haivghurst, R. J. (1948). Developmental tasks and education. Chicago: University of Chicago Press.

Immisch, F. (2011). Bindungsorientierte Verhaltenstherapie. Behandlung der Veränderungsresistenz bei Kindern und Jugendlichen. Tübingen: DGVT.

Kerns, K. A., \& Stevens, A. C. (1996). Parent-child attachment in late adolescence: Links to social relations and personality. Journal of Youth and Adolescence, 25, 323-342.

Klemenz, B. (2009). Ressourcenorientierte Erziehung. Tübingen: DGVT.

Krajewski, E., Dittrich, K., \& Borg-Laufs, M. (2010). Psychische Grundbedürfnisse in der offenen Jugendarbeit. In M. Borg-Laufs \& K. Dittrich (Eds.), Psychische Grundbedürfnisse in Kindheit und Jugend. Perspektiven für Soziale Arbeit und Psychotherapie (pp. 173-196). Tübingen: DGVT.

Krus, A. (2004). Mut zur Entwicklung: Das Konzept der psychomotorischen Entwicklungstherapie. Schorndorf: Hofmann.

Maccoby, E. E. (1980). Social development: Psychology, growth and the parent-childrelationship. New York: Harcourt Brace Jovanovich. 
Maslow, A. (1954). Motivation and personality. New York: Harper \& Row. Mattejat, F. (2008). Entwicklungsorientierte Verhaltenstherapie mit Kindern, Jugendlichen und ihren Familien. Verhaltenstherapie mit Kindern und Jugendlichen, 4, 77-88.

Mischel, W., Ayduck, O., Berman, M. G., Casey, B. J., Gotlib, I. H., Jonides, J., ... Shoda, Y. (2011). 'Willpower' over the life span: Decomposing self-regulation. Social Cognitive and Affective Neuroscience, 6, 252-256.

Petersen, L. E., Stahlberg, D., \& Dauenheimer, D. (2000). Selbstkonsistenz und Selbstwerterhöhung: Der integrative Selbstschemaansatz. In W. Greve (Ed.), Psychologie des Selbst (pp. 239-254). Weinheim: Beltz.

Rohleder, J. (2010). Die Befriedigung der psychischen Grundbedürfnisse als Gegenstand der Schulsozialarbeit. In M. Borg-Laufs \& K. Dittrich (Eds.), Psychische Grundbedürfnisse in Kindheit und Jugend. Perspektiven für Soziale Arbeit und Psychotherapie (pp. 149-172). Tübingen: DGVT.

Rybak, C., Maharjan, C. L. M., \& Adhikari, A. (2010). Emotional intelligence in the educational and therapeutic community in Nepal. Journal of Education and Research, 2, 35-43.

Rygaard, N. P. (2006). Severe attachment disorder in childhood: A guide to practical therapy. Berlin: Springer.

Schwarzer, R., \& Jerusalem, M. (2002). Das Konzept der Selbstwirksamkeit. Zeitschrift für Pädagogik, Beiheft, 44, 28-53.

Shakya, D. R. (2010). Psychiatric morbidity profiles of child and adolescent psychiatry out-patients in a tertiary-care hospital. Journal of Nepal Paediatric Society, 30(2), 79-84.

Siqueland, E. R. (1968). Reinforcement patters and extinction in human newborns. Journal of Experimental Child Psychology, 6, 431-432.

Spitz, R. (1971). Hospitalismus I, II. In G. Bittner \& E. Schmid-Cords (Eds.), Erziehung in früher Kindheit (pp. 77-103). München: Piper.

Thimm, K. (2000). Schulverweigerung. Zur Begründung eines neuen Verhältnisses von Sozialpädagogik und Schule. Münster: Votum.

Tol, W. A., Jordans, M. J. D., Regmi, S., \& Sharma, B. (2005). Cultural challenges to psychosocial counseling in Nepal. Transcultural Psychiatry, 42, 317-333.

Tol, W. A., Jordans, M. J., Keen, A. S., \& Pradhan, H. (2007). Psychosocial counselling in Nepal: Perspectives of counsellors and beneficiaries. International Journal for the Advancement of Counselling, 1, 57-68.

Von Klitzing, K. (2009). Reaktive Bindungsstörungen. Heidelberg: Springer.

Vygotski, L. S. (1986). Language and thought.Cambridge, MA: The Mit-Press.

Wagner, E. (2010). Zur Befriedigung psychischer Grundbedürfnisse bei aggressiven Jugendlichen. In M. Borg-Laufs \& K. Dittrich (Eds.), Psychische Grundbedürfnisse in Kindheit und Jugend. Perspektiven für Soziale Arbeit und Psychotherapie (pp. 39-58). Tübingen: DGVT-Verlag.

Zeneah, C., Smyke, A. T., Koga, S. F., \& Carlson, E. (2005). Attachment in institutionalized and community children in Romania. Child Development, 76, 1015-1028. 